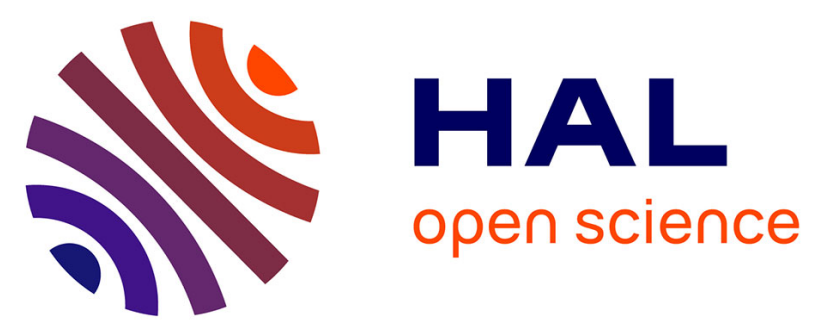

\title{
Vulnerability assessment of livestock and grasslands to climate change and extreme events (VALIDATE project)
}

Jean-François Soussana, Giorgio Alessio, Jean Louis Durand, René Baumont, Florence Volaire, Jacques Roy, Sandra Lavorel, Xavier Le Roux, Nicolas Viovy, Francoise Ruget, et al.

\section{To cite this version:}

Jean-François Soussana, Giorgio Alessio, Jean Louis Durand, René Baumont, Florence Volaire, et al.. Vulnerability assessment of livestock and grasslands to climate change and extreme events (VALIDATE project). IARU International Scientific Congress on Climate Change: Global Risks, Challenges and Decisions, Mar 2009, Copenhague, Denmark. IOP Publishing, IOP Conference Series: Earth and Environmental Science, 6, 2009, IOP Conference Series: Earth and Environmental Science. 10.1088/1755-1307/6/4/242047. hal-01186942

\section{HAL Id: hal-01186942 \\ https://hal.science/hal-01186942}

Submitted on 4 Jun 2020

HAL is a multi-disciplinary open access archive for the deposit and dissemination of scientific research documents, whether they are published or not. The documents may come from teaching and research institutions in France or abroad, or from public or private research centers.
L'archive ouverte pluridisciplinaire HAL, est destinée au dépôt et à la diffusion de documents scientifiques de niveau recherche, publiés ou non, émanant des établissements d'enseignement et de recherche français ou étrangers, des laboratoires publics ou privés. 
P24.39

Vulnerability assesment of livestock and grasslands to climate change and extreme events (VALIDATE project)

Jean-Francois Soussana(1), GA Alessio(1), JL Durand(2), R Baumont(3), F Volaire(4), J Roy(5), S

Lavorel(6), X Le Roux(7), N Viovy(8), F Ruget(9), M Duru(10), PA Jayet(11), L Terray(12) et al.

(1) INRA UR 874, UREP Clermont-Ferrand, France

(2) INRA, UR P3F, Lusignan, France

(3) INRA UR1213, URH, Theix, France

(4) UMR 1230 SYSTEM, Montpellier, France

(5) UMR 5175 CEFE, Montpellier, France

(6) UMR 5553 LECA, Grenoble, France

(7) UMR 5557 LEM Villeurbanne, France

(8) UMR 1572 LSCE Gif/Yvette, France

(9) UMR 1114 EMMAH Avignon, France

(10) UMR 1248 AGIR Toulouse, France

(11) UMR 210 EP Grignon, France

(12) CERFACS Toulouse, France

The main objective of the VALIDATE project is to integrate extreme events into the assessment of impacts, adaptation and vulnerability to climate change in the grasslands and livestock sector. The project is centred on France. Then the simulations of impacts on grassland productivity and of feedbacks on climate through changes in carbon sequestration and in $\mathrm{N} 2 \mathrm{O}$ and $\mathrm{CH} 4$ emissions will be extended to Europe. Our primary hypothesis is that the negative effects of a few extreme events may surpass the positive effects of a rise in atmospheric $\mathrm{CO} 2$ and of a moderate average $2-3^{\circ} \mathrm{C}$ warming (Porter and Semenov, 2005, Tubiello et al., 2007) on pasture productivity. A key objective of the project is to test this hypothesis using a combination of experimental and modelling approaches.

VALIDATE will evaluate for France the vulnerability of grasslands and livestock to climate change and extreme events, combining ecosystem manipulation experiments and modelling at three different scales such as from the plot, to the farm and to the region. High resolution climate scenarios based on a statistical disagregation of precipitations will be used both for experiments and simulations. Three complementary experiments, using major scientific infrastructures (ORE, long-term ecological research and French ECOTRON) are invested. At four contrasted sites (Alps to Mediterranee), the experiments will test the effects of heat and drought extremes on grasslands acclimated, or not, to the mean climate conditions (temperature and precipitations) and to the CO2 concentration projected for 2050 by scenarios (Fig. 1).

Two key mechanistic pasture models (PASIM and STICS) will be further developed by introducing heat and drought response functions (plant mortality, plant and animal physiology, soil functioning). The models will be parameterised and evaluated with the three complementary experiments and then used for simulating for France and Europe impacts (frequency and thresholds, Fig. 2) of downscaled climate scenarios on grasslands, in terms of potential production (forage, meat and milk) and of climate feedbacks (net fluxes of $\mathrm{CO}_{2}, \mathrm{~N}_{2} \mathrm{O}$ and $\mathrm{CH}_{4}$ ) (Vuichard et al., 2007) (Fig. 3). Farm models forced by the scenarios will simulate in two contrasted regions (Bretagne, Massif-Central) the adaptations of livestock breeding practices and the vulnerability of livestock farms. Moreover, the ORCHIDEE biosphere model, which includes PASIM and STICS, will be used in its version coupled to the economic model AROPAGE to simulate adaptations and vulnerability of farming systems and agricultural land use. Finally, based on the results of the project, a stakeholders dialog will allow an assessment of the vulnerability of grasslands and livestock to climate change in France. 

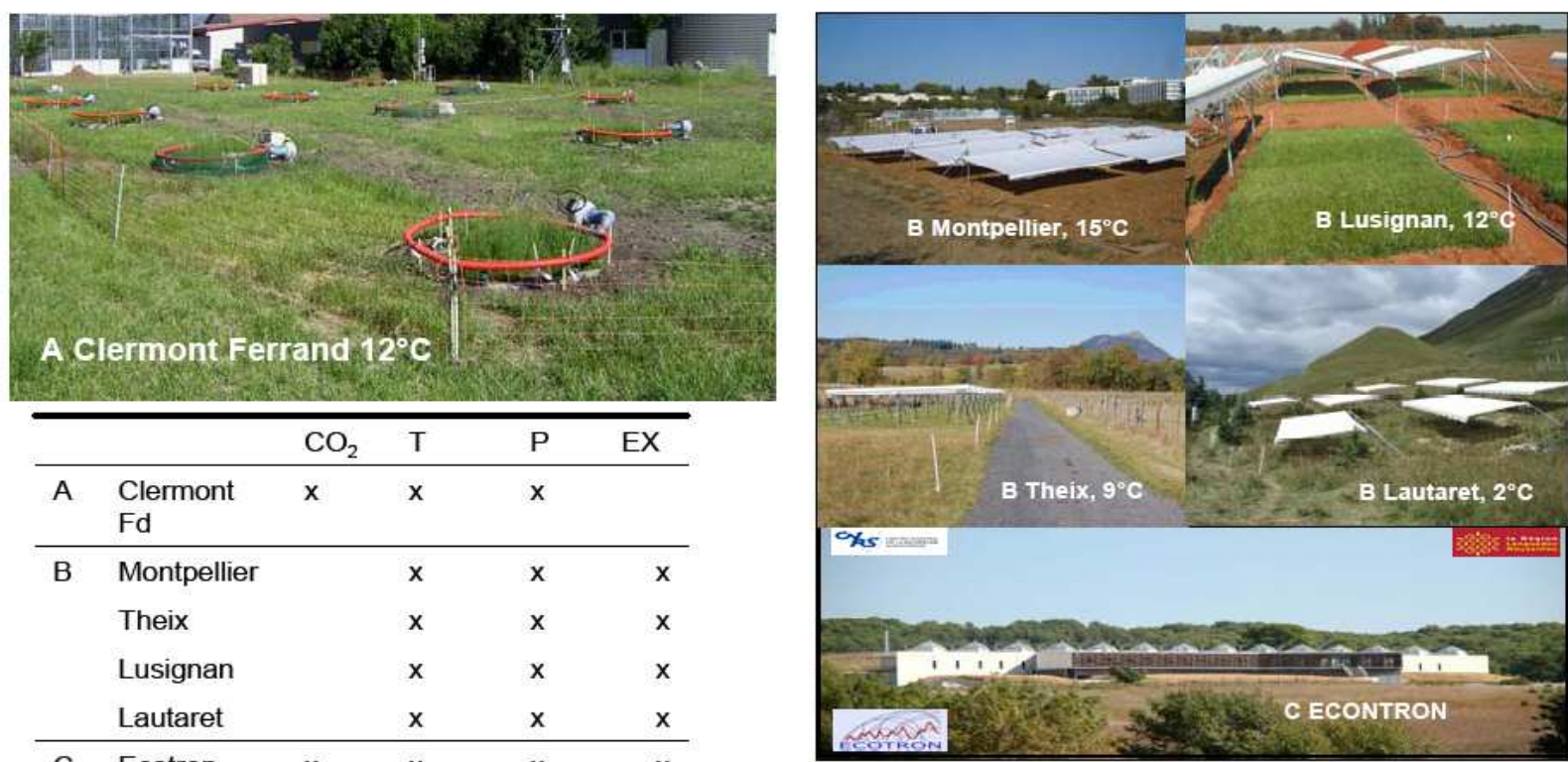

\begin{tabular}{llllll}
\hline & & $\mathrm{CO}_{2}$ & $\mathrm{~T}$ & $\mathrm{P}$ & $\mathrm{EX}$ \\
\hline $\mathrm{A}$ & Clermont & $\mathrm{x}$ & $\mathrm{x}$ & $\mathrm{x}$ & \\
& $\mathrm{Fd}$ & & & & \\
\hline $\mathrm{B}$ & Montpellier & & $\mathrm{x}$ & $\mathrm{x}$ & $\mathrm{x}$ \\
& Theix & $\mathrm{x}$ & $\mathrm{x}$ & $\mathrm{x}$ \\
& Lusignan & $\mathrm{x}$ & $\mathrm{x}$ & $\mathrm{x}$ \\
& Lautaret & & $\mathrm{x}$ & $\mathrm{x}$ & $\mathrm{x}$ \\
\hline $\mathrm{C}$ & Ecotron & $\mathrm{x}$ & $\mathrm{x}$ & $\mathrm{x}$ & $\mathrm{x}$ \\
\hline
\end{tabular}

Figure 1. Three types of ecosystem manipulation experiments with warming $(\mathrm{T})$, rain exclusion $(\mathrm{P})$ and elevated CO2. A single extreme (EX) heat and drought event will be applied in summer 2009.

\section{References}

Porter, J. R., and Semenov, M. A., (2005). Crop responses to climatic variation. Philosophical Transactions of the Royal Society B-Biological Sciences 360(1463): 2021-2035.

Tubiello, F., Soussana, J. F., Howden, S. M., and Easterling, W. (2007). Crop and pasture response to climate change. PNAS, 104: 19686-19690.

Vuichard, N., Ciais, P., Viovy N., Calanca, P., and Soussana, J.F. (2007). Estimating the greenhouse gas fluxes of European grasslands with a process-based model: 2. Simulations at the continental level. Global Biogeochemical Cycles 21 GB1005, doi:10.1029/2005GB002612: 13p. 